\title{
Transmission of Colletotrichum truncatum and Macrophomina phaseolina by lima bean seeds
}

\author{
José Monteiro da Mota ${ }^{1}$, Maruzanete Pereira de Melo ${ }^{1}$, Mynor Efraín Munguía García ${ }^{1}$, Enayra Silva Sousa ${ }^{1}$, \\ Emanoela Maria de Jesus Sousa ${ }^{1}$, Beatriz Meireles Barguil ${ }^{2}$, José Evando Aguiar Beserra Jr ${ }^{1}$
}

${ }^{1}$ Universidade Federal do Piauí, Centro de Ciências Agrárias, Departamento de Fitotecnia, Campus Universitário Ministro Petrônio Portella, s/n Bairro - Ininga, Teresina - PI, Brazil, CEP 64049-550. Universidade Estadual do Piauí, Centro de Ciências da Natureza, Rua João Cabral, 2231, bairro Pirajá, Teresina - PI, Brazil, CEP 64002-150

Autor para correspondência: José Evando Aguiar Beserra Jr. (evando@ufpi.edu.br).

Data de chegada: 09/06/2017. Aceito para publicação em: 12/07/2018.

$10.1590 / 0100-5405 / 180868$

\section{ABSTRACT}

Mota, J.M., Melo, M.P., García, M.F.M.; Sousa, E.S.; Sousa, E.M.J.; Barguil, B.M.; Beserra Jr, J.E.A. Transmission of Colletotrichum truncatum and Macrophomina phaseolina by lima bean seeds. Summa Phytopathologica, v.45, n.1, p.33-37, 2019.

The fungi Colletotrichum truncatum and Macrophomina phaseolina are among the main pathogens associated with lima bean seeds in Brazil, and they are the causal agents of anthracnose and charcoal rot, respectively. The aim of this study was to verify the seed-seedling transmission of $C$. truncatum and M. phaseolina in artificially inoculated lima bean seeds. Potato-dextrose-agar (PDA) media with different hydric potentials were obtained after the addition of mannitol. Isolates of C. truncatum and M. phaseolina were peaked to these media. Forty grams of seeds were distributed over the fungal mycelium, remaining there for different exposure periods, as a function of each treatment: T1: $0.0 \mathrm{MPa}$ without inoculum for $48 \mathrm{~h}$; T2: $0.0 \mathrm{MPa}$ for $48 \mathrm{~h}$; T3: $-0.2 \mathrm{MPa}$ for $48 \mathrm{~h}$; T4: - $0.4 \mathrm{MPa}$ for $48 \mathrm{~h}$; T5: -0.6 MPa for $72 \mathrm{~h}$; T6: $-0.8 \mathrm{MPa}$ for 96 $\mathrm{h}$ and T7: $-1.0 \mathrm{MPa}$ for $120 \mathrm{~h}$. The seeds were incubated at $25^{\circ} \mathrm{C}$ under a 12-hour photoperiod. Germination in a paper roll, emergence of seedlings in sand and seed health in PDA were evaluated. T4 provided the best conditions to temporarily prevent seed germination, promoting a greater incidence of seeds infected by $C$. truncatum and a greater percentage of diseased plants. $M$. phaseolina reduced seed germination, independently of the inoculated treatment. Both fungi were transmitted from the seeds to the seedlings of lima bean, causing symptoms in various aerial parts. C. truncatum and M. phaseolina transmission rate was $83.1 \%$ and $76.46 \%$, respectively.

Keywords: Germination, Phaseolus lunatus, seed health, transmission by seeds.

\section{RESUMO}

Mota, J.M., Melo, M.P., García, M.F.M.; Sousa, E.S.; Sousa, E.M.J.; Barguil, B.M.; Beserra Jr, J.E.A. Transmissão de Colletotrichum truncatum e Macrophomina phaseolina por sementes de feijão-fava. Summa Phytopathologica, v.45, n.1, p.33-37, 2019.

Os fungos Colletotrichum truncatum e Macrophomina phaseolina estão entre os principais patógenos associados a sementes de feijão-fava no Brasil, sendo os agentes causais da antracnose e da podridão de carvão, respectivamente. Este trabalho teve como objetivo verificar a transmissão semente-plântula de C. truncatum e $M$. phaseolina em sementes de feijão-fava inoculadas artificialmente. Meios de cultura batata-dextrose-agar (BDA) com diferentes potenciais hídricos foram obtidos após a adição de manitol. Isolados de $C$. truncatum e M. phaseolina foram repicados para esses meios. Quarenta gramas de sementes foram distribuídas sobre o micélio fúngico, permanecendo por diferentes períodos de exposição, em função do tratamento: T1: 0,0 MPa sem inóculo por 48 h; T2: 0,0 MPa por 48 h; T3: - 0,2 MPa por 48 h; T4: -0,4 MPa por 48 h; T5: -0,6 MPa por $72 \mathrm{~h}$; T6: - 0,8 MPa por $96 \mathrm{~h}$ e T7: -1,0 MPa por 120 h. As sementes foram incubadas a $25^{\circ} \mathrm{C}$, com fotoperíodo de 12 horas. Foram avaliadas a germinação em rolo de papel, a emergência de plântulas em areia e a sanidade de sementes em BDA. O T4 proporcionou melhores condições para impedir temporariamente a germinação das sementes, promovendo maior incidência de sementes infectadas por $C$. truncatum e maior porcentagem de plântulas doentes. M. phaseolina reduziu a germinação das sementes, independente do tratamento inoculado. Ambos os fungos foram transmitidos das sementes para as plântulas de feijão-fava, causando sintomas em diferentes órgãos aéreos. A taxa de transmissão de C. truncatum e M. phaseolina foi de $83,1 \%$ e $76.46 \%$, respectivamente.

Palavras-chave: Germinação, Phaseolus lunatus, sanidade de sementes, transmissão por sementes.

Seeds can efficiently harbor and transport microorganisms of all taxonomic groups, pathogenic or not, and are thus excellent dispersion vehicles and initial inoculum sources in the field, being capable of starting epidemics. Low seed quality is considered one of the main causes of low yield in plantations because the association of pathogens with seeds can have negative effects on the germination process and seedling development (7).

In lima bean (Phaseolus lunatus L.) plantations in Brazil, fungi are among the main causal agents of diseases. Anthracnose caused by Colletotrichum truncatum (Schw.) Andrus \& Moore frequently occurs and is considered one of the main diseases of lima bean, especially in the Northeastern region, where the weather conditions favor its development (14). Another fungus that has a deleterious action on leguminous seeds is Macrophomina phaseolina (Tassi) Goid., which can cause failure before and after seedling emergence $(1,8)$. Development of the fungus is stimulated by high temperatures and low humidity (9).

Transmission of Colletotrichum spp., the cause of various diseases in legumes, is known to occur in seeds, contributing to the largescale spread of these pathogens (10). One example is Colletotrichum lindemuthianum (Sacc. Magnus) Cavara, which is transmitted efficiently with seed-seedling transmission rates of up to $80 \%$ in common bean (Phaseolus vulgaris L.) (15). 
Studies related to the effect of seed health often need seeds to be infected by pathogens in quantity and quality sufficient for research. The inoculation of fungi using the hydric restriction method has been used in investigation involving germination, pathogen transmission and seed health (11). The efficiency of the method was demonstrated in studies on the transmission of C. truncatum, Phomopsis sojae Lehman and Sclerotinia sclerotiorum (Lib.) de Bary in soybean (Glycine max (L.) Merrill) seeds (12) and of Fusarium oxysporum f. sp. phaseoli Kendrick et Snyder in common bean (6).

As there is the need for information about seed-seedling transmission of C. truncatum and M. phaseolina, which will subsidize the implementation of appropriate management measures, this study proposed to verify the transmission of these two pathogens from artificially infected lima bean seeds.

\section{MATERIALS AND METHODS}

Lima bean seeds var. Boca de Moça were disinfected in a sodium hypochlorite solution $(\mathrm{NaOCl}) 1 \%$, for three minutes, followed by two washes with sterile distilled water. Then, they were subjected to tests of germination in a paper roll, seedling emergence in sand, and health tests $(4 ; 5)$. The fungal isolates COUFPI29 (Colletotrichum truncatum) and COUFPI37 (Macrophomina phaseolina) used in this study were obtained from lima bean seeds collected in March 2015 from the county of Esperantina and Teresina, Piauí State, respectively.

The culture medium used in this study was Potato-dextrose-agar (PDA) added of mannitol, obtaining the hydric potentials of -0.2 ; $-0.4 ;-0.6 ;-0.8 ;-1.0 \mathrm{MPa}$. The concentrations of solutes for medium preparation, at each hydric potential, were obtained by means of the Van't Hoff formula (17), namely: yos = RTC, in which: yos = osmotic potential $(\mathrm{atm}) ; \mathrm{R}=$ ideal gas constant $\left(8.32 \mathrm{~J} \mathrm{~mol}^{-1} \mathrm{~K}^{-1}\right)$; $\mathrm{T}$ $=$ temperature $(\mathrm{K}) ; \mathrm{C}=$ concentration $\left(\mathrm{mol} \mathrm{L}^{-1}\right)$ and $\mathrm{T}(\mathrm{K})=273+\mathrm{T}$ $\left({ }^{\circ} \mathrm{C}\right)$. The culture media were autoclaved at $121{ }^{\circ} \mathrm{C}$ for $20 \mathrm{~min}$ and distributed in Petri dishes of $15 \mathrm{~cm}$ diameter. Each plate was added of three PDA discs containing structures of the isolate (C. truncatum or M. phaseolina). The plates were incubated under a $12 \mathrm{~h}$ photoperiod and temperature of $25 \pm 1{ }^{\circ} \mathrm{C}$ until total fungal growth; then, 40 grams of seeds were deposited on the fungal mycelia, remaining there for different exposure periods, depending on the treatment.

The treatments consisted of different binomials of hydric potential / exposure time of seeds to the fungus, being: T1. 0.0 MPa without inoculum for $48 \mathrm{~h}$ (control); T2. 0.0 MPa for $48 \mathrm{~h}$; T3. - $0.2 \mathrm{MPa}$ for $48 \mathrm{~h}$; T4 - $0.4 \mathrm{MPa}$ for $48 \mathrm{~h}$; T5. -0.6 MPa for $72 \mathrm{~h}$; T6. - $0.8 \mathrm{MPa}$ for $96 \mathrm{~h}$ and T7. $-1.0 \mathrm{MPa}$ for $120 \mathrm{~h}$. Evaluation of germination was in paper roll, that of seedling emergence was in sand and that of seed health was in PDA.

Germination test in paper roll: the seeds were placed on sterile filter paper sheets, totaling 25 seeds per treatment and 16 replicates. The conditions of the experiment followed the rules of seed analysis (5). Germinated seeds and dead seeds were recorded.

Emergence tests in sand: these were carried out in plastic trays of 47 x 27 x $08 \mathrm{~cm}$ containing sterile autoclaved sand $\left(121^{\circ} \mathrm{C}\right.$ for two hours). All 100 seeds used per treatment were sown at a depth of $1.5 \mathrm{~cm}$. The trays were randomly distributed in a greenhouse. The evaluations were carried out at seven, 14 and 21 days after sowing (DAS) for the seeds inoculated with $C$. truncatum and at seven and 14 DAS for the seeds inoculated with M. phaseolina. Evaluation included the number of emerged seedlings and the incidence of seedlings with symptoms.
The non-germinated seeds and seedlings were pulled up and evaluated, and fragments of organs were plated in PDA medium to check the presence of the fungus. Data on fungal transmission from the seed to the seedling were expressed as percentages for each plant organ, evaluated as a function of the incidence of fungus.

Health test: six seeds per $15 \mathrm{~cm}$-diameter Petri dish were evaluated, totaling 120 seeds per treatment. The seeds were plated in PDA medium and maintained in an incubator at $25 \pm 1{ }^{\circ} \mathrm{C}$, in a regime alternating 12 hours of light. The evaluation occurred at up to seven days after sowing, based on visual analysis and using a stereoscopic microscope (19). Total transmission rate (T.R.) was determined for each treatment using the formula described (20): TR $(\%)=[\operatorname{IR}(\%)$ / IS (\%)] * 100, where: IR = infection rate of C. truncatum and $M$. phaseolina determined by analyzing the data (pre-emergence death and asymptomatic transmission rate), IS $=$ Incidence of $C$. truncatum and $M$. phaseolina determined by the health test in inoculated seeds.

The assays were carried out in completely randomized design, and means were compared according to Tukey's test at 5\%. Statistical analysis was carried out by using ANOVA in the ASSISTAT program, version 7.7 beta (18).

\section{RESULTS AND DISCUSSION}

The increase in hydric potential / exposure time promoted a gradual reduction in the percentage of germinated seeds and a consequent increase in the number of dead seeds (Figure 1A). There were high germination rates in treatments $\mathrm{T} 2, \mathrm{~T} 3, \mathrm{~T} 4$ and $\mathrm{T} 5(\mathrm{P}<0.05)$, inoculated with C. truncatum, as observed in the non-inoculated control (Figure 1A). In these treatments, the presence of the fungus only slightly affected the germination power of seeds. T6 and T7 were the treatments that promoted the highest seed mortality in germination test roll. Osmotic potentials of $-0.8 \mathrm{MPa}$ or higher and times from 96 hours onwards normally inhibit the germination of seeds of other plant species, as is the case for cotton seeds (Gossypium hirsutum L.) inoculated with $C$. gossypii var. cephalosporioides (2) and soybean seeds inoculated with C. truncatum (11).

When the seeds were inoculated with M. phaseolina, independently of the time of exposure and of the presence (T3, T4, T5, T6 and T7) or absence of hydric potential, there was a sharp reduction in germination (Figure 1A). Seed germination fell from $73.5 \%$ in the non-inoculated treatment (T1) to $21.2 \%$ in the inoculated treatment (T2); in other words, the presence of the fungus under the evaluated conditions caused widespread death of the seeds, possibly due to the long exposure period and the high aggressiveness of the fungus. In cotton seeds, at 48 hours onwards of exposure to the fungus Botryodiplodia theobromae, there was a reduction of $80 \%$ in germination (13).

There was a reduction in the number of seedlings emerging in sand as the level of hydric restriction and the time of exposure increased (Figure 1B), and this was similar to the result of the germination test in the paper roll (Figure 1A).

For C. truncatum, treatments T2, T3 and T4 did not differ $(\mathrm{P}<0.05)$ from the non-inoculated control treatment $(\mathrm{T} 1)$, with an mean emergence percentage of $88.5 \%$, demonstrating that the rise in the hydric potential did not interfere with seedling development. T6 presented the lowest germination percentage, with only $36 \%$ seedlings emerging, not differing from T7 (Figure 1B).

Symptoms were observed (spots on cotyledons, stems and leaves) in the seedlings that came from seeds inoculated with $C$. truncatum 


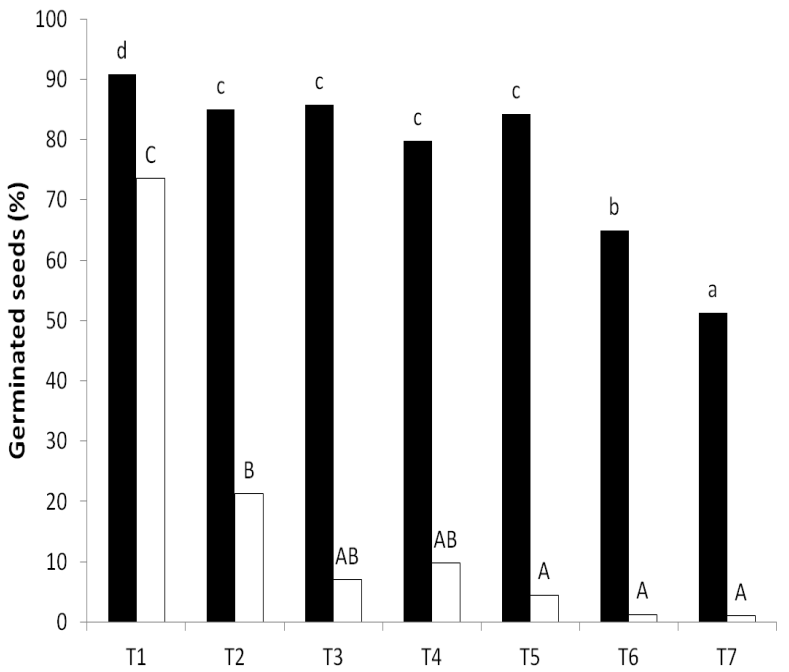

B

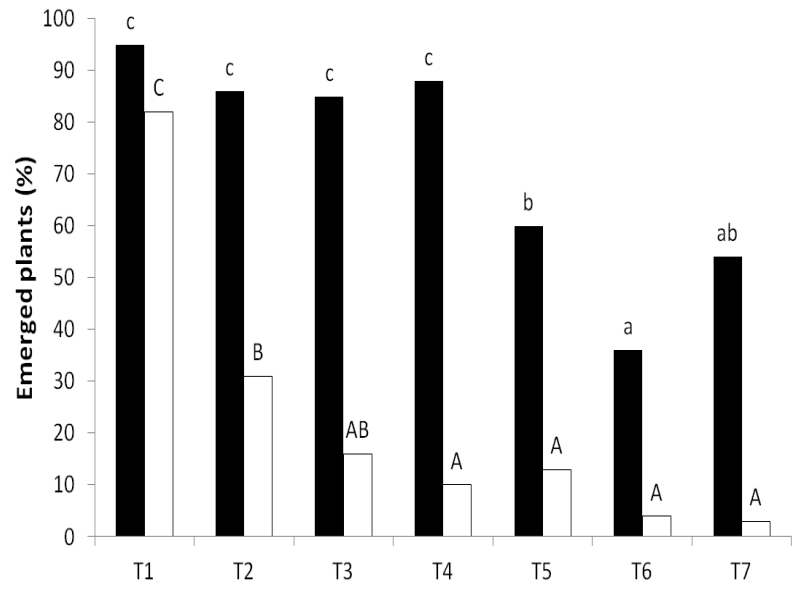

C

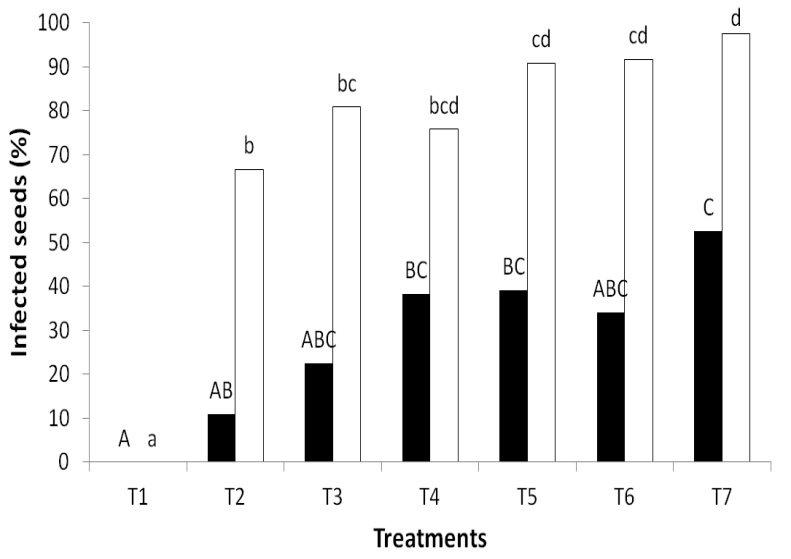

Figure 1. Germination in a paper roll (A), emergence in sand (B) and health test in potato-dextrose-agar medium (C) for seeds of lima bean (Phaseolus lunatus L.) inoculated with Colletotrichum truncatum and Macrophomina phaseolina in different treatments (hydric potentials and time of exposure to the fungus). Means followed by the same letter do not differ statistically according to Tukey's test at 5\%. T1. 0.0 MPa without inoculum for $48 \mathrm{~h}$; T2. 0.0 MPa with inoculum for $48 \mathrm{~h}$; T3. -0.2 MPa for $48 \mathrm{~h}$; T4. -0.4 MPa for $48 \mathrm{~h}$; T5. -0.6 MPa for $72 \mathrm{~h}$; T6. $-0.8 \mathrm{MPa}$ for $96 \mathrm{~h}$ and T7. $-1.0 \mathrm{MPa}$ for $120 \mathrm{~h}$. Black column (D): $C$. truncatum; White column ( $\square$ ): M. phaseolina.
(Figure 2A), from 7 DAS onwards, and these became more severe at 14 and 21 DAS. At 7 DAS the incidence of symptoms was more frequent in treatments $\mathrm{T} 4$ and $\mathrm{T} 5(\mathrm{P}<0.05)$, dropping in treatments $\mathrm{T} 6$ and $\mathrm{T} 7$. At 14 DAS there was no difference among the inoculated treatments $(\mathrm{P}<0.05)$. At $21 \mathrm{DAS}$ there was, in general, an increase in the incidence of symptoms and there was no statistically significant difference among treatments $\mathrm{T} 4, \mathrm{~T} 6$ and $\mathrm{T} 7$. These results, added to those regarding emergence in sand, indicate T4 (-0.4 MPa and $48 \mathrm{~h}$ exposure) as the best treatment for inoculation of lima bean seeds with $C$. truncatum because it did not interfere in seed germination and provided a higher incidence of symptoms in the seedling (Figure 1B).

Similar results were found for cotton seeds inoculated with $C$. gossypii var. cephalosporioides, which presented a reduction in the number of seedlings emerging at 7 DAS in the treatments in which the hydric restriction was -0.8 and $-1.0 \mathrm{MPa}$. At $21 \mathrm{DAS}$ no significant differences were found among treatments (13).

For the seeds inoculated with M. phaseolina there was a reduction in the percentage of emerged seedlings in all inoculated treatments (Figure 1B). There was $82 \%$ seedling emergence in treatment T1, only $31 \%$ in treatment $\mathrm{T} 2$, and lower values in the following treatments, demonstrating the high aggressiveness of the fungus, which is capable of penetrating and killing the seed in the absence of the restrictor. Furthermore, the exposure period of 48 hours seems to be enough to establish the fungal infection, which corroborates the results of the germination test (Figure 1A).

At 21 DAS symptoms could not be evaluated for M. phaseolina due to the high incidence and severity of the symptoms, which led to the death of the seedlings (Figure 2B). At 7 DAS the health of the seedlings was already compromised, independent of the treatment, with $79.8 \%$ plants showing symptoms even in the treatment with no hydric restrictor added and exposed to the fungus for 48 hours (T2). Treatments T5, T6 and T7 presented 100\% diseased plants. This result was also maintained in the second evaluation at 14 DAS.

These results, together with those from emergence in sand, revealed that the methodology was efficient in obtaining lima bean seeds infected with M. phaseolina, but due to the high aggressiveness of the pathogen, which seems to make the seed deteriorate rapidly, the used parameters may not have been appropriate. New experiments with exposure times below 48 hours will be carried out. The high aggressiveness of $M$. phaseolina was proven after the inoculation of common bean seeds with 96 isolates of the pathogen obtained in various countries, among which was Brazil (16).

With the aim of guaranteeing that the symptoms observed in the seedlings were indeed caused by C. truncatum and M. phaseolina, different organs were collected from $10 \%$ seedlings in each treatment after the last evaluation. For the seedlings emerged from seeds inoculated with $C$. truncatum, the fungus was re-isolated from cotyledons, stems and leaves, with mean percentages of 58.2, 33.2 and $56.4 \%$, respectively (Table 1A), which attests not only to the efficiency of the hydric restriction method in the inoculation of lima bean seeds, but also to the fact that the pathogen is transmitted from the seed to the seedlings. Mean percentages of 76.7, 55.3 and $30.5 \%$ were obtained from seedlings that emerged from seeds inoculated with M. phaseolina in the cotyledons, stems and leaves, respectively (Table 1B).

Lower percentages of diseased plants were found in a study (3) which sought to confirm the transmission of Bipolaris sorokiniana from seeds to seedlings of barley (Hordeum vulgare L.).. They found aerial and root organs infected by the fungus in coleoptiles (40\%), apical extremity $(38.6 \%)$, below-ground region $(48.1 \%)$, sheaths $(31.6 \%)$, 
A

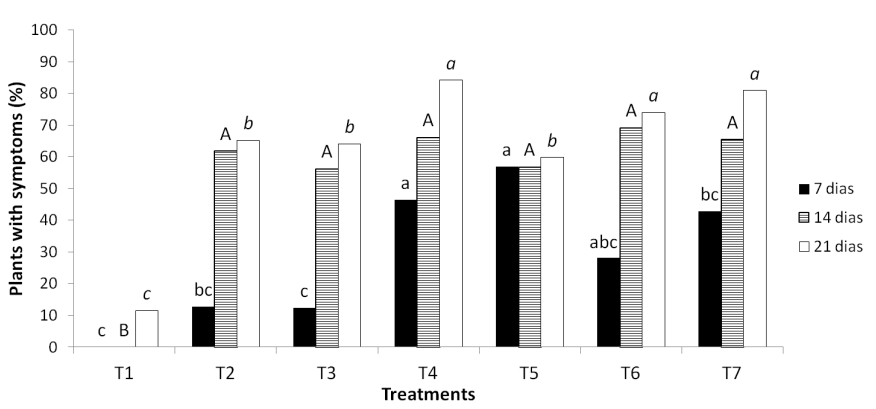

B

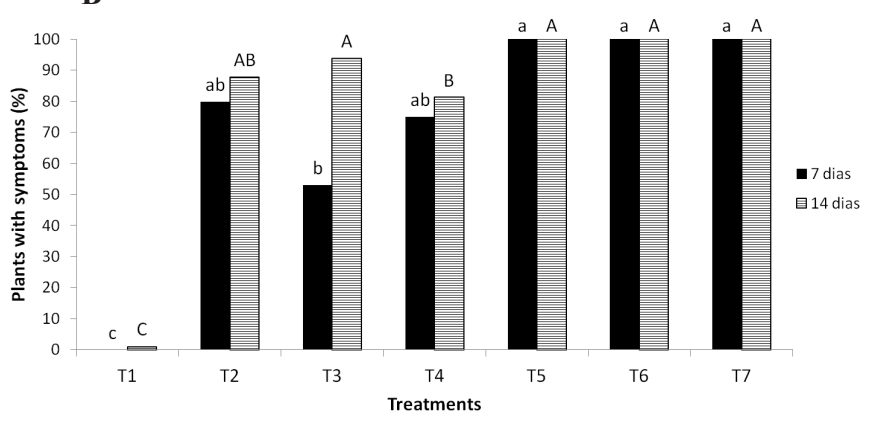

Figure 2. Lima bean seedlings (Phaseolus lunatus L.) with symptoms caused by infection with Colletotrichum truncatum (A) and Macrophomina phaseolina (B) in different treatments (hydric potentials and time of exposure to the fungus). Means followed by the same letter do not differ statistically according to Tukey's test at 5\%. Column 7 days: lowercase letters, column 14 days: capital letters, column 21 days: lowercase letters in italics. T1. 0.0 MPa without inoculum for $48 \mathrm{~h}$; T2. 0.0 MPa with inoculum for $48 \mathrm{~h}$; T3. -0.2 MPa for $48 \mathrm{~h}$; T4. $-0.4 \mathrm{MPa}$ for $48 \mathrm{~h}$; T5. -0.6 MPa for $72 \mathrm{~h}$; T6. -0.8 MPa for $96 \mathrm{~h}$ and T7. -1.0 MPa for $120 \mathrm{~h}$.

Table 1. Percentage of Colletotrichum truncatum (A) and Macrophomina phaseolina (B) recovered from organs of lima bean (Phaseolus lunatus L.) seedlings that emerged after inoculation of seeds subjected to different treatments.

(A)

\begin{tabular}{cccc}
\hline Treatment & Cotyledons & Stem & Leaf \\
\hline T1* & 0.0 & 18.0 & 18.1 \\
T2 & 26.3 & 20.0 & 31.4 \\
T3 & 48.1 & 15.0 & 40.0 \\
T4 & 71.8 & 30.0 & 57.1 \\
T5 & 86.1 & 60.0 & 74.2 \\
T6 & 96.8 & 45.0 & 80.0 \\
T7 & 78.5 & 45.0 & 94.2 \\
\hline Mean (\%) & 58.2 & 33.2 & 56.4 \\
\hline
\end{tabular}

(B)

\begin{tabular}{cccc} 
T1 & 0.0 & 0.0 & 0.0 \\
T2 & 62.5 & 40.0 & 10.0 \\
T3 & 100.0 & 70.0 & 10.0 \\
T4 & 90.0 & 83.3 & 50.0 \\
T5 & 84.6 & 100.0 & 76.9 \\
T6 & 100.0 & 44.4 & 66.6 \\
T7 & 100.0 & 50.0 & 0.0 \\
\hline Mean (\%) & 76.7 & 55.3 & 30.5 \\
\hline
\end{tabular}

*T1. 0.0 MPa without inoculum for $48 \mathrm{~h}$; T2. 0.0 MPa with inoculum for $48 \mathrm{~h}$; T3. -0.2 MPa for $48 \mathrm{~h}$; T4. -0.4 MPa for $48 \mathrm{~h}$; T5. -0.6 MPa for $72 \mathrm{~h}$; T6. - 0.8 MPa for $96 \mathrm{~h}$ and T7. $-1.0 \mathrm{MPa}$ for $120 \mathrm{~h}$.

plumules (8.1\%) and mesocotyls (28.1\%).

From the results of the health test in PDA medium for the two evaluated pathogens, it was noted that the inoculum of both penetrated the seeds in all binomials (hydric potential / time), causing infection (Figure 1C). Seeds inoculated with C. truncatum, in T7, presented higher incidence $(52.5 \%)$. In this treatment, however, there was a high incidence of ungerminated seeds, making them unviable for obtaining seeds infected by the pathogen. In treatments T4 and T5 there was fungal incidence of about $38.7 \%$; in addition to this result, these treatments barely affected seed germination and seedling emergence (Figures $1 \mathrm{~A}$ and $1 \mathrm{~B}$ ). Seeds inoculated with $M$. phaseolina presented high incidences, reaching 97.5\% in T7 (Figure 1C). The lowest incidence among the inoculated treatments was $66.7 \%$ in $\mathrm{T} 2$.

Considering the pre-emergence death and asymptomatic transmission rate, as well as the incidence of fungi on seeds, the infection (IR) and transmission (TR) rates for C. truncatum and $M$. phaseolina were calculated considering treatment 2. For C. truncatum IR was $9 \%$ and TR was $83.1 \%$. For M. phaseolina IR was $51 \%$ and TR reached $76.46 \%$.

The use of hydric restriction can be efficient in obtaining lima bean seeds infected with $C$. truncatum in order to conduct research that needs infected seeds, such as in studies of chemical treatment of seeds, epidemiology and development of methods to detect pathogens. However, appropriate times need to be established, apparently less than 48 hours of exposure to $M$. phaseolina, due to the death rate in seeds when exposed for long periods.

\section{ACKNOWLEDGEMENTS}

JMM and ESS thanks Coordination for the Improvement of Higher Education Personnel (CAPES) for granting a scholarship and MPM thanks CAPES for granting PNPD fellowship. MEMG thanks the Coimbra Group of Brazilian Universities (GCUB) and the Department of Human Development and Education of the Organization of American States (OAS) for granting a scholarship.

\section{REFERENCES}

1. Almeida, A.M.R.; Seixas, C.D.S.; Farias, J.R.B.; Oliveira, M.C.N.; Franchini, J.C.; Debiasi, H.; Costa, J.M.; Gaudêncio, C.A. Macrophomina phaseolina em soja. Londrina: Embrapa Soja, 2014. n. 346, 2014.

2. Araújo, A.E.; Menten, J.O.M.; Dias, C.T.S.; Czermainski, A.B.C.; Santos, J.W.; Moraes, M.H.D. Efeito de restritores hídricos sobre a germinação, comprimento da radícula e níveis de detecção de Colletotrichum gossypii var. cephalosporioides em sementes de algodão. Summa Phytopathologica, Botucatu, v.38, n.1, p.79-83, 2012. 
3. Barba, J.T.; Reis, E.M.; Forcelini, C.A. Efeito da temperatura e de fungicida na transmissão de Bipolaris sorokiniana da semente para plântulas de cevada. Fitopatologia Brasileira, Fortaleza, v.27, n.5 , p. 500-507, 2002.

4. Brasil. Ministério da Agricultura, Pecuária e Abastecimento. Secretaria de Defesa Agropecuária. Manual de análise sanitária de sementes. Brasília, DF: MAPA, 2009. 200p.

5. Brasil, Ministério da Agricultura, Pecuária e Abastecimento. Regras para Análise de Sementes. Secretaria de Defesa Agropecuária. - Brasília: Mapa/ ACS, 2009b. 399 p.

6. Costa, M.L.N.; Machado, J. C.; Guimarães, R.M.; Pozza, E.A.; Oride, D. Inoculação de Fusarium oxysporum f. sp. phaseoli em sementes de feijoeiro através de restrição hídrica. Ciência e Agrotecnologia, Lavras, v.27, n.5, p.1023-1030, 2003.

7. Dhingra, O.D. Teoria da transmissão de patógenos fúngicos por sementes. In: Zambolim, L. Sementes: qualidade fitossanitária. Viçosa: UFV, 2005. p.75-104.

8. Gupta, G.K.; Sharma, S.K.; Ramteke, R. Biology, epidemiology and management of the pathogenic fungus Macrophomina phaseolina (Tassi) Goid with special reference to charcoal rot of soybean (Glycine max (L.) Merrill). Journal of Phytopathology, Maldem, v.160, n.1, p.167-180, 2012.

9. Kendig, S.R.; Rupe, J.C.; Scott, H.D. Effect of irrigation and soil water stress on densities of Macrophomina phaseolina in soil and roots of two soybean cultivars. Plant Disease, Saint Paul, v.84, p.895-900, 2000.

10. Lenné, J.M. Colletotrichum diseases of legumes. In: Bailey, J.A.; Jeger, M.J. Colletotrichum: biology, pathology and control. Wallingford: CAB International, 1992. p.134-166.

11. Machado, J.C.; Barrocas, E.N.; Guimarães, R.M.; Machado, C.F. Uso da técnica de restrição hídrica ou condicionamento osmótico em patologia de sementes. Revisão Anual de Patologia de Plantas, Passo Fundo, v.20, n.1, p.37-63, 2012.

12. Machado, J.C.; Oliveira, J.A.; Vieira, M.G.G.C.; Alves, M.C. Inoculação artificial de sementes de soja por fungos, utilizando solução de manitol Revista Brasileira de Sementes, Londrina, v.23, n.2, p.95-101, 2001.

13. Machado, J.C.; Oliveira, J.A.; Vieira, M.G.G.C.; Alves, M.C. Uso da restrição hídrica na inoculação de fungos em sementes de algodoeiro (Gossypium hirsutum). Revista Brasileira de Sementes, Londrina, v.26, n.1, p.62-67, 2004.

14. Paula Júnior, T.J.; Silva, M.B.; Vieira, R.F. Doenças causadas por fungos em hortaliças leguminosas. Informe Agropecuário, Belo Horizonte, v.17, n.182, p.63-71, 1995.

15. Rey, M.S. Transmissão semente-plântula de Colletotrichum lindemuthinum em feijão (Phaseolus vulgaris). Arquivos do Instituto Biológico, São Paulo, v.76, n.3, p.465-470, 2009.

16. Reyes-Franco, M.C.; Delgado, H.S.; Fernandez, B.R.; Fernandez, M.M.; Simpson, J.; Perez, M.N. Pathogenic and genetic variability within $\mathrm{Ma}$ crophomina phaseolina from México and other countries. Journal of Phytopathology, Maldem, v.154, p.447-453, 2006.

17. Salisbury, F.B; Ross, C.W. Plant physiology. Belmont: Wadsworth, 1991. $682 \mathrm{p}$.

18. Silva, F.A.S.; Azevedo, C.A.V. Versão do programa computacional Assistat para o Sistema operacional Windows. Revista Brasileira de Produtos Agroindustriais, Campina Grande, v. 4, n.1, p. 71-78, 2002.

19. Sutton, B.C. The Coelomycetes. London: Common Wealth Mycological Institute, 1980. 696p.

20. Teixeira, H.; Machado, J.C. Transmissibility and effect of Acremonium strictum in maize seeds. Ciência e Agrotecnologia, Lavras, v.27, n.5, p.1045-1052, 2003. 